\title{
Genetic divergence and path analysis in wheat cultivars under heat stress ${ }^{1}$
}

\author{
Carlos Eduardo da Silva Oliveira² ${ }^{2}$ Agner de Freitas Andrade ${ }^{3}$, \\ André Zoz ${ }^{4}$, Renato Lustosa Sobrinho ${ }^{5}$, Tiago $\mathrm{Zoz}^{3}$
}

\section{ABSTRACT}

One of the biggest limitations for the wheat crop expansion to Brazilian tropical regions is the high temperature in the rainy season. This study aimed to select, based on genetic divergence and path analysis, cultivars that tolerate cultivation in the summer (heat stress). Nine wheat cultivars were sown, using a randomized block design with three replications, with plots consisting of 10 rows of $6 \mathrm{~m}$ and row spacing of $0.15 \mathrm{~m}$. The highest grain yield and number of ears $\mathrm{m}^{-2}$ were observed for the CD 150 cultivar and the largest 1,000-grain weight for CD 116. BRS 220, IPR 136, IPR 144 and BRS Pardela had the highest number of sterile spikelets. The highest number of grains per ear was observed for CD 150, CD 116, BRS Pardela, IPR 130 and IPR 85 , showing direct effects on grain yield, evidenced by the path analysis. CD 116 and CD 150 were the most productive cultivars and can be considered as possible parents in wheat breeding programs. IPR 85, CD 116, CD 108 and CD 150 showed a greater tolerance to high temperatures.

KEYWORDS: Triticum aestivum, genotypic correlations, hightemperature tolerance, wheat crop expansion.

\section{INTRODUCTION}

For decades, the wheat cultivation in Brazil was predominant in a temperate climate zone extending from the Rio Grande do Sul to the Paraná state (Cargnin et al. 2006). As it presents adequate climatic conditions for the development of this cereal, southern Brazil still has the largest cultivated area (2.1 million hectares) (Conab 2020). Wheat cultivation in the Brazilian Savanna is an

\section{RESUMO}

Divergência genética e análise de trilha em cultivares de trigo sob estresse térmico

Uma das maiores limitações da expansão da triticultura para regiões tropicais do Brasil é a elevada temperatura no período chuvoso. Objetivou-se selecionar, com base na divergência genética e análise de trilha, cultivares que toleram ser cultivadas no verão (estresse térmico). Foram semeadas 9 cultivares de trigo, com delineamento experimental em blocos ao acaso e três repetições, sendo as parcelas constituídas por 10 linhas de $6 \mathrm{~m}$, com espaçamento de $0,15 \mathrm{~m}$. A maior produtividade e número de espigas $\mathrm{m}^{-2}$ ocorreram para a cultivar CD 150 e a maior massa de mil grãos para CD 116. BRS 220, IPR 136, IPR 144 e BRS Pardela tiveram maior número de espiguetas estéreis. O maior número de grãos por espiga foi verificado para CD 150, CD 116, BRS Pardela, IPR 130 e IPR 85, apresentando efeito direto na produtividade de grãos por meio da análise de trilha. CD 116 e CD 150 foram as mais produtivas, podendo ser consideradas possíveis genitoras em programas de melhoramento de trigo. IPR 85, CD 116, CD 108 e CD 150 mostraram maior tolerância a altas temperaturas.

PALAVRAS-CHAVE: Triticum aestivum, correlações genotípicas, tolerância a alta temperatura, expansão tritícola.

alternative for its expansion, as long as requirements such as altitude and appropriate cultivar choice are met (Oliveira Neto \& Santos 2017). In the 1970s, wheat began to be cultivated on a commercial scale in the central region of Brazil (São Paulo, Minas Gerais, Goiás, Mato Grosso and Mato Grosso do Sul states), and, since the 1990s, it has been cultivated in Brazilian Savanna soils, under no-tillage, reaching high grain yields (Souza \& Ramalho 2001). The main limitation for obtaining a high wheat grain yield in

1 Received: Sep. 04, 2020. Accepted: Oct. 29, 2020. Published: Dec. 05, 2020. DOI: 10.1590/1983-40632020v5065493.

${ }^{2}$ Universidade Estadual Paulista, Faculdade de Engenharia, Ilha Solteira, SP, Brasil.

E-mail/ORCID: carllos_eduard@hotmail.com/0000-0002-3894-9559.

${ }^{3}$ Universidade Estadual de Mato Grosso do Sul, Departamento de Fitotecnia, Cassilândia, MS, Brasil.

E-mail/ORCID: agner_freitas@hotmail.com/0000-0001-6809-0944,zoz@uems.br/0000-0003-2991-5485.

${ }^{4}$ Universidade Estadual Paulista, Faculdade de Ciências Agronômicas, Botucatu, SP, Brasil.

E-mail/ORCID: andre_zoz@hotmail.com/0000-0002-9879-9871.

${ }^{5}$ University of Antwerp, Department of Biology, Antwerp, Belgium.

E-mail/ORCID: renato.lustosasobrinho@uantwerpen.be/0000-0003-2176-6745. 
this region is the occurrence of high temperatures; thus, the choice of heat-tolerant cultivars is essential (Souza \& Ramalho 2001).

The basic objectives of breeding programs for cultivated plants are the selection and recommendation of high-yield genotypes. The selection process is frequently based on the genotypes' performance in different environments (Cargnin et al. 2006). With the increase in temperature due to global warming, the concern has been adapting existing cultivars to the stressful conditions of high temperatures (Naudts et al. 2014). The development of high-yield wheat cultivars requires important strategies to maintain the crop grain yield without affecting other important traits. This is done through indirect selection, in which characteristics are directly related to grain yield and high heritability (Moral et al. 2003). A breeder's success depends, among several factors, on the genetic variability present in the studied population (Koundinya et al. 2013).

The characterization of genotypes used in breeding programs provides useful information to understand and take advantage of their diversity (Cerqueira-Silva et al. 2014). Studies on this genetic diversity provide basic information about parents, joining genotypes in heterotic groups and obtaining segregating populations with a greater variability in crossings (Bianchi et al. 2017). Thus, this study aimed to verify the direct and indirect effects of traits via path analysis on grain yield, as well as to quantify the genetic divergence among wheat cultivars grown under heat-stress conditions.

\section{MATERIAL AND METHODS}

The experiment was carried out at the Estância Zoz (53 $44^{\circ} \mathrm{W}, 24^{\circ} 22^{\prime} \mathrm{S}$ and altitude of $\left.380 \mathrm{~m}\right)$, in Maripá, Paraná state, Brazil, in an area conducted under no-tillage for 12 years. Before implementing the experiment, the area was cultivated with a succession of soybean and corn, in the 2009/2010 harvest. The soil is classified as Latossolo Vermelho Eutroférrico [clayey Oxisol (Rhodic Haplustox); USA (2014)], with a very clayey textural class (Santos et al. 2013). Before the implementation of the experiment, the soil chemical and particle size properties were analyzed (Table 1).

The region's climate, according to the Köppen classification, is type Cfa, humid subtropical (mesothermal), with hot summers showing a tendency to concentrate rainfall (average temperature above $22{ }^{\circ} \mathrm{C}$ ) and winters with unusual frosts (average temperature below $18^{\circ} \mathrm{C}$ ), without a defined station. While conducting the experiment, rainfall and temperature data were collected (Figure 1).

The experimental design was randomized blocks, with three replications. The treatments consisted of nine wheat cultivars (Table 2) and the plots of 10 rows, spaced $0.15 \mathrm{~m}$ apart, with $6.0 \mathrm{~m}$ long. The six central rows were used for the evaluations, disregarding $1.0 \mathrm{~m}$ at the end of each plot. The population density of 350 seeds $\mathrm{m}^{-2}$ was adopted for all cultivars, and the sowing was carried out on November 13, 2010. Heat-stress was defined by the cultivation being carried out during the Brazilian summer, when temperatures reached approximately $35^{\circ} \mathrm{C}$, which is harmful to the germination and growth of wheat plants. Because they are plants that accumulate degree-days to reach their flowering stage, they also shortened their cycle (Souza \& Ramalho 2001).

For sowing fertilization, $20 \mathrm{~kg} \mathrm{ha}^{-1}$ of nitrogen, $100 \mathrm{~kg} \mathrm{ha}^{-1}$ of potassium and $100 \mathrm{~kg} \mathrm{ha}^{-1}$ of phosphorus were applied. According to the soil chemical analysis, liming was not necessary, and the seeds were treated with insecticide and fungicide [thiamethoxam + lambda-cyhalothrin $\left(0.2 \mathrm{~L} \mathrm{ha}^{-1}\right.$ of c.p. $)$ and propiconazole ( $0.5 \mathrm{~L} \mathrm{ha}^{-1}$ of c.p.), respectively].

Table 1. Soil chemical ${ }^{(1)}$ and particle-size ${ }^{(2)}$ properties before the experiment was implemented.

\begin{tabular}{|c|c|c|c|c|c|c|c|c|c|c|c|c|}
\hline $\begin{array}{c}\text { Layer } \\
\mathrm{cm}\end{array}$ & $\mathrm{Ca}$ & $\mathrm{Mg}$ & $\mathrm{K}$ & $\begin{array}{c}\mathrm{Al} \\
\mathrm{cmol}_{\mathrm{c}}\end{array}$ & $\begin{array}{l}\mathrm{H}+\mathrm{Al} \\
\mathrm{n}^{-3} \\
\end{array}$ & SB & CEC & $\begin{array}{c}\mathrm{OM} \\
\mathrm{g} \mathrm{dm}^{-3}\end{array}$ & $\begin{array}{c}\text { SB } \\
\end{array}$ & $\mathrm{Al}$ & $\begin{array}{c}\mathrm{P} \\
\mathrm{mg} \mathrm{dm}^{-3}\end{array}$ & $\begin{array}{c}\mathrm{pH} \\
(\mathrm{CaCl})\end{array}$ \\
\hline $0-20$ & 7.01 & 1.17 & 0.71 & 0.00 & 4.96 & 8.89 & 13.85 & 31.97 & 64.19 & 0.00 & 21.29 & 5.10 \\
\hline $20-40$ & 7.10 & 1.93 & 0.75 & 0.00 & 5.76 & 9.78 & 15.54 & 25.49 & 62.93 & 0.00 & 10.40 & 4.90 \\
\hline \multicolumn{4}{|c|}{ Sand } & \multicolumn{5}{|c|}{ Silt } & \multicolumn{4}{|c|}{ Clay } \\
\hline \multicolumn{4}{|c|}{103.0} & \multicolumn{5}{|c|}{123.4} & \multicolumn{4}{|c|}{773.6} \\
\hline
\end{tabular}

${ }^{(1)}$ Pavan et al. (1992); ${ }^{(2)}$ pipette method (Santos et al. 2013). 

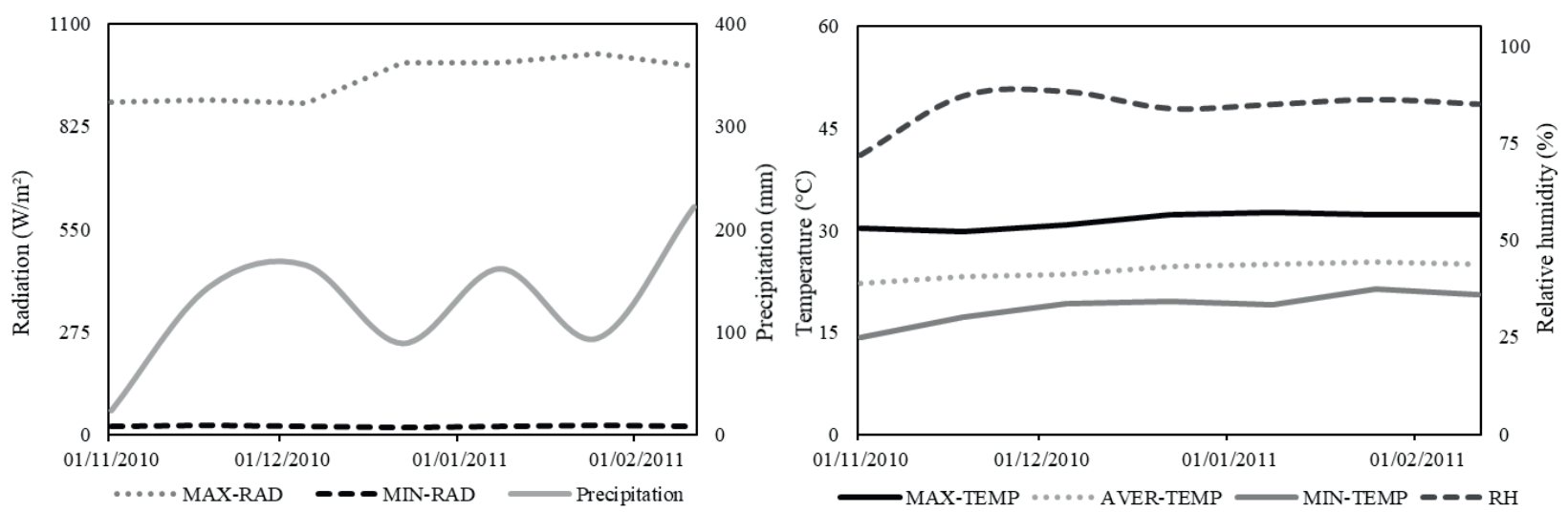

Figure 1. Precipitation accumulated every 15 days, minimum and maximum radiation (a), relative air humidity, and minimum, average and maximum temperatures (b), during the experiment (November 2010 to February 2011).

Table 2. Cycle, average heading and maturation, plant height and 1,000-grain weight of the wheat cultivars used in the experiment.

\begin{tabular}{llcccc}
\hline \multirow{2}{*}{ Cultivar } & Cycle & Average heading & \begin{tabular}{c} 
Average maturation \\
Plant height \\
\cline { 3 - 5 } cm
\end{tabular} & $\begin{array}{c}\text { 1,000-grain weight } \\
\mathrm{g}\end{array}$ \\
\hline BRS 220 & Medium & 69 & 122 & 84 & 37 \\
BRS Pardela & Medium & 67 & 122 & 79 & 36 \\
CD 108 & Super early & 52 & 109 & 67 & 32 \\
CD 116 & Early & 62 & 115 & 77 & 35 \\
CD 150 & Early & 59 & 114 & 68 & 39 \\
IPR 130 & Medium & 67 & 118 & 80 & 39 \\
IPR 136 & Medium & 67 & 113 & 80 & 34 \\
IPR 144 & Early & 65 & 113 & 83 & 37 \\
IPR 85 & Early & 60 & & 85 & 47 \\
\hline
\end{tabular}

During the conduction of the experiment, two preventive applications of fungicides and two applications for insect control were carried out with the combination of a contact and a systemic insecticide. Topdressing fertilization was carried out at the beginning of the tillering phase, at 10 days after emergence, applying $80 \mathrm{~kg} \mathrm{ha}^{-1}$ of $\mathrm{N}$ in the form of urea.

At the end of the crop cycle, the following variables were evaluated: number of ears $\mathrm{m}^{-2}: 4.0 \mathrm{~m}$ were demarcated within the plot's useful area, and then the ears were counted. The data were converted to ears $\mathrm{m}^{-2}$; plant height $(\mathrm{cm}): 10$ plants were selected within the plot's useful area, and then the distance between the soil surface and the top of the ear was evaluated; number of sterile spikelets per ear: 20 ears were collected within the plot's useful area, and the spikelets without grain were counted and considered sterile spikelets; number of grains per ear: 20 ears were collected within the plot's useful area, and then the number of grains per ear was counted; 1,000-grain weight (g): eight samples of 100 grains were collected from each plot and weighed with a precision scale $(0.0001 \mathrm{~g})$; grain yield $\left(\mathrm{kg} \mathrm{ha}^{-1}\right)$ : all plants in the useful area were collected and threshed. After cleaning, the grain mass was weighed and corrected to $13 \%$ of moisture. The data were converted to $\mathrm{kg} \mathrm{ha}^{-1}$.

The data were submitted to preliminary tests of normality and homoscedasticity. As the data for all variables showed normal distribution and homogeneous variances, they were subjected to analysis of variance. The F-test measured the significance of the mean squares obtained in the analysis of variance at $5 \%$ of probability. The averages for the wheat cultivars were grouped by the Scott-Knott test at $5 \%$ of probability.

The phenotypic, genotypic and environmental correlations among the evaluated characteristics were estimated using variance and covariance analysis. From the values observed for the traits $\mathrm{X}$ and $\mathrm{Y}$ in the same genotype, the variance analysis was performed 
for each trait separately and also for the sum of them $(X+Y)$ (Cruz et al. 2012). From the variance analysis of the traits $\mathrm{X}, \mathrm{Y}$ and the sum $\mathrm{X}+\mathrm{Y}$, the average product of the genotypes and the average product of the error were obtained. Based on the average product of the genotypes, average product of the error, average square of the genotypes, average square of the error and number of repetitions, the phenotypic, genotypic and environmental correlation coefficients were estimated. The coefficients of genotypic correlation were divided into direct and indirect effects of the evaluated traits (independent variables) on grain yield (dependent variable), using path analysis (Wright 1921).

The obtained data were used to carry out the genetic divergence analysis, applying the Tocher optimization method (Rao 1952). The generalized Mahalanobis distance $\left(\mathrm{D}^{2}\right)$ was used as a measure of dissimilarity. The illustrative dendrogram of the dissimilarity pattern was prepared according to the unweighted pair group method with arithmetic mean (UPGMA), using the Genes software (Cruz 2013).

\section{RESULTS AND DISCUSSION}

There was difference between the wheat cultivars for number of ears $\mathrm{m}^{-2}$, plant height, number of sterile spikelets per ear, number of grains per ear, 1000-grain weight and grain yield (Table 3). Therefore, it can be said that there is genetic variability among the wheat cultivars evaluated under heat-stress conditions.

The heritability coefficients ranged from $68.07 \%$ for number of sterile spikelets per ear to $99.41 \%$ for 1,000 -grain weight (Table 3 ). These values show the low effect of the environment on these traits. It is noteworthy that the selection of traits with heritability close to $100 \%$ allows significant selection gains in the initial generations; however, with the reduction of genetic variability, these selection gains are significantly reduced (Silva et al. 2015). The coefficients of experimental variation ranged from $3.82 \%$ for 1,000-grain weight to $31.46 \%$ for number of sterile spikelets per ear (Table 3). The coefficient of genetic variation $(\mathrm{CVg})$ ranged from $6.84 \%$ for plant height to $74.57 \%$ for grain yield (Table 3 ).

The traits with the highest $\mathrm{CVg}$ values have a greater genetic variation; therefore, they have a greater potential for selection. The $\mathrm{CVg}$ /coefficient of experimental variation ( $\mathrm{CVe}$ ) ratio ranged from 1.77 for plant height to 12.99 for 1,000-grain weight (Table 3 ). In all the evaluated traits, the $\mathrm{CVg} / \mathrm{CVe}$ ratio had values greater than 1.00 , what is very important, since $\mathrm{CVg} / \mathrm{CVe}$ ratios greater than 1.00 indicate that the genetic variation is superior to the environmental variation, what favors the selection of plants with a greater efficiency and less environmental effect (Vencovsky \& Barriga 1992).

There was no difference in plant height among the evaluated cultivars (Table 4). The highest grain yield and number of ears $\mathrm{m}^{-2}$ were observed for the CD 150 cultivar, with averages of $1,110 \mathrm{~kg} \mathrm{ha}^{-1}$ and 452 ears $\mathrm{m}^{-2}$, respectively (Table 4 ). The CD 150 cultivar, with a dose of $\mathrm{N}$ similar to the one used in the present study, reached a grain yield of $2,185 \mathrm{~kg} \mathrm{ha}^{-1}$ in Cascavel (Paraná state, Brazil), in the winter season (Oliveira et al. 2011). However, the average grain yield of the evaluated wheat cultivars was $605.07 \mathrm{~kg} \mathrm{ha}^{-1}$, showing an effect of heat-stress, since,

Table 3. Summary of the analysis of variance and genetic parameters for the number of ears $\mathrm{m}^{-2}(\mathrm{NE})$, plant height (PH), number of sterile spikelets per ear (SSE), number of grains per ear (NGE), 1,000-grain weight (W1000) and grain yield of wheat cultivars.

\begin{tabular}{|c|c|c|c|c|c|c|}
\hline \multirow{2}{*}{ Source of variation } & \multicolumn{6}{|c|}{ - Mean square } \\
\hline & Yield & W1000 & NGE & SSE & $\mathrm{NE}$ & $\mathrm{PH}$ \\
\hline Block & $13,278.52$ & 0.43 & 2.95 & 0.06 & 201.36 & 1.86 \\
\hline Genotype & $203,564.99 * *$ & $232.82 * *$ & $24.07 * *$ & $2.62 * *$ & $18,877.98^{* *}$ & $14.60^{*}$ \\
\hline Residue & $10,597.01$ & 1.38 & 6.52 & 0.47 & $1,846.21$ & 4.66 \\
\hline Var G & $64,322.66$ & 77.15 & 5.85 & 0.72 & $5,677.25$ & 3.31 \\
\hline$h^{2}$ & 94.79 & 99.41 & 72.91 & 82.08 & 90.22 & 68.07 \\
\hline $\mathrm{CVe}(\%)$ & 17.01 & 3.82 & 9.58 & 31.46 & 14.44 & 3.86 \\
\hline $\mathrm{CVg}(\%)$ & 74.57 & 49.59 & 18.41 & 74.33 & 46.18 & 6.84 \\
\hline $\mathrm{CVg} / \mathrm{CVe}$ & 4.38 & 12.99 & 1.92 & 2.36 & 3.20 & 1.77 \\
\hline
\end{tabular}


Table 4. Grain yield, 1,000-grain weight (W1000), number of grains ear ${ }^{-1}$ (NGE), number of sterile spikelets ear ${ }^{-1}$ (SSE), number of ears $\mathrm{m}^{-2}(\mathrm{NE})$ and plant height $(\mathrm{PH})$ of wheat cultivars.

\begin{tabular}{|c|c|c|c|c|c|c|}
\hline \multirow{2}{*}{ Cultivar } & Yield & W1000 & \multirow{2}{*}{ NGE } & \multirow{2}{*}{ SSE } & \multirow{2}{*}{ NE } & $\mathrm{PH}$ \\
\hline & $\mathrm{kg} \mathrm{ha}^{-1}$ & $\mathrm{~g}$ & & & & $\mathrm{~cm}$ \\
\hline IPR 144 & $317.13 \mathrm{~d}^{*}$ & $20.10 \mathrm{f}$ & $24.57 \mathrm{~b}$ & $2.80 \mathrm{a}$ & $376.86 \mathrm{~b}$ & 53.50 \\
\hline IPR 136 & $330.62 \mathrm{~d}$ & $21.43 \mathrm{f}$ & $21.80 \mathrm{~b}$ & $3.27 \mathrm{a}$ & $229.01 \mathrm{~d}$ & 54.50 \\
\hline IPR 130 & $426.33 \mathrm{~d}$ & $26.07 \mathrm{e}$ & $27.40 \mathrm{a}$ & $2.07 \mathrm{~b}$ & $314.60 \mathrm{c}$ & 55.33 \\
\hline BRS 220 & $477.48 \mathrm{~d}$ & $26.47 \mathrm{e}$ & $24.47 b$ & $3.47 \mathrm{a}$ & $311.27 \mathrm{c}$ & 56.33 \\
\hline BRS Pardela & $569.13 \mathrm{c}$ & $31.20 \mathrm{~d}$ & $28.40 \mathrm{a}$ & $2.73 \mathrm{a}$ & $210.11 \mathrm{~d}$ & 53.00 \\
\hline IPR 85 & $641.73 \mathrm{c}$ & $43.13 \mathrm{~b}$ & $26.93 \mathrm{a}$ & $1.80 \mathrm{~b}$ & $214.56 \mathrm{~d}$ & 57.33 \\
\hline CD 108 & $706.40 \mathrm{c}$ & $29.30 \mathrm{~d}$ & $25.73 \mathrm{~b}$ & $0.93 \mathrm{~b}$ & $286.81 \mathrm{c}$ & 56.00 \\
\hline CD 116 & $866.84 \mathrm{~b}$ & $45.43 \mathrm{a}$ & $29.87 \mathrm{a}$ & $1.47 \mathrm{~b}$ & $282.36 \mathrm{c}$ & 60.33 \\
\hline CD 150 & $1,110.00 \mathrm{a}$ & $33.77 \mathrm{c}$ & $30.73 \mathrm{a}$ & $1.07 \mathrm{~b}$ & $452.45 \mathrm{a}$ & 56.67 \\
\hline Mean & 552.02 & 30.77 & 26.66 & 2.18 & 297.56 & 55.89 \\
\hline
\end{tabular}

* Means followed by the same letter in the column belong to the same group by the Scott-Knott test at $5 \%$ of probability.

in the winter season of 2010, the average grain yield was $2,978 \mathrm{~kg} \mathrm{ha}^{-1}$ in the same region of the present study (Hubner 2010). The number of ears $\mathrm{m}^{-2}$ is the main component linked to grain yield in wheat. In the winter of 2011, approximately 430 ears $\mathrm{m}^{-2}$ were found in the same cultivar, in Palotina (Paraná state, Brazil) (Coan et al. 2013).

The largest 1,000-grain weight was observed for CD 116, followed by IPR 85, both higher than the others (Table 4). The 1,000-grain weight of CD 116 increased by approximately $22 \%$, concerning the characterization from the breeding company that released this cultivar, what may be caused by the smaller plant population, causing a greater compensation for the reduction of plants $\mathrm{m}^{-2}$, results that are linked to the cultivar tolerance to high temperatures (Table 2), similarly to those obtained by Coan et al. (2013), in winter cultivation, in Palotina, the same cultivation region, with 1,000-grain weight of $42.4 \mathrm{~g}$. The cultivars CD 150, CD 116, BRS Pardela, IPR 130 and IPR 85 had the highest number of grains per ear. However, the heat stress decreased the number of grains per ear in all cultivars, mainly for CD 116 and CD 150, in agreement with Coan et al. (2013), who, in the winter cultivation of 2011, in Palotina, found a number of grains per ear for the CD 116 and CD 150 cultivars in the range of 48 and 40 grains, respectively, approximately $38 \%$ and $24 \%$ higher than the same cultivars in the summer cultivation.

BRS 220, IPR 136, IPR 144 and BRS Pardela had the highest number of sterile spikelets per ear (Table 4). All the adverse effects verified in the evaluated traits may be explained due to the heat- stress effect to what the wheat plants were submitted. The ideal temperature for wheat cultivation is between 18 and $24^{\circ} \mathrm{C}$, and, when the temperatures exceed this range, they start to compromise the plant metabolic processes and become critical, causing irreversible damage to the crop development (Oliveira Neto \& Santos 2017), such as reducing the viability of pollen grains by temperatures above $32{ }^{\circ} \mathrm{C}$ (Harsant et al. 2013). Above $30^{\circ} \mathrm{C}$, the photosynthetic rate, number of grains per plant and grain weight begin to decrease and damage the formation of ovules, making them unviable, due to the high temperature accelerating the process of vegetative and reproductive development (Narayanan 2018).

There were positive and significant genotypic and phenotypic correlations between grain yield and number of ears $\mathrm{m}^{-2}$, plant height, number of grains per ear and 1,000-grain weight. Negative and significant genotypic and phenotypic correlations were also found between grain yield and number of sterile spikelets (Table 5). There was also a negative and significant environmental correlation between grain yield and plant height and number of sterile spikelets, and a positive and significant environmental correlation between grain yield and number of grains per ear and 1,000-grain weight (Table 5). Vieira et al. (2007) evaluated the primary and secondary components of grain yield in wheat and realized that the primary factors that have a great influence and importance in determining the grain yield are the number of grains per spikelet and the number of tillers $\mathrm{m}^{-1}$, which result in the increase of ears in the area. Correlations linked alone to plant height may indirectly affect the grain yield. These 
Table 5. Estimates of genotypic (G) and environmental (E) correlation coefficients among the evaluated traits in wheat genotypes.

\begin{tabular}{llccccc}
\hline & & NE & PH & SSE & NGE & W1000 \\
\hline \multirow{2}{*}{ PH } & G & $0.045^{\text {ns }}$ & - & - & - & - \\
& $\mathrm{E}$ & $0.151^{*}$ & - & - & - & - \\
SSE & $\mathrm{G}$ & $-0.375^{* *}$ & $-0.824^{* *}$ & - & - & - \\
& $\mathrm{E}$ & $0.215^{* *}$ & $0.374^{* *}$ & - & - & - \\
NGE & $\mathrm{G}$ & $0.389^{* *}$ & $0.711^{* *}$ & $-0.685^{* *}$ & - & - \\
& $\mathrm{E}$ & $-0.003^{\text {ns }}$ & $-0.136^{*}$ & $-0.658^{* *}$ & - & - \\
$\mathrm{W} 1000$ & $\mathrm{G}$ & $-0.206^{* *}$ & $0.987^{* *}$ & $-0.641^{* *}$ & $0.806^{* *}$ & - \\
& $\mathrm{E}$ & $0.055^{\text {ns }}$ & $-0.472^{* *}$ & $-0.029^{\text {ns }}$ & $0.176^{* *}$ & - \\
Yield & $\mathrm{G}$ & $0.423^{* *}$ & $0.825^{* *}$ & $-0.849^{* *}$ & $0.915^{* *}$ & $0.705^{* *}$ \\
& $\mathrm{E}$ & $-0.015^{\text {ns }}$ & $-0.358^{* *}$ & $-0.379^{* *}$ & $0.491^{* *}$ & $0.310^{* *}$ \\
\hline
\end{tabular}

NE: number of ears $\mathrm{m}^{-2}$, PH: plant height (cm); SSE: number of sterile spikelets ear ${ }^{-1}$, NGE: number of grains ear ${ }^{-1}$; W1000: 1,000-grain weight $(\mathrm{g})$; yield: $\mathrm{kg} \mathrm{ha}^{-1}$. **, * Significant at $1 \%$ and $5 \%$ of probability, respectively, by the t-test.

effects are also attributed to the environmental effects on the physiological mechanisms that control the expression of these traits subjected to stress (Carvalho et al. 2004).

All genotypic correlations related to all the evaluated traits were negatively affected by the number of sterile spikelets. The genotypic correlations of the 1,000-grain weight were negatively affected by the number of ears $\mathrm{m}^{-2}$ and number of sterile spikelets; however, positive effects of high magnitude for the number of grains per ear and plant height were observed. There was a negative environmental correlation for the 1,000-grain weight, concerning height, and a positive one for the number of grains per ear (Table 5). Dutano et al. (2015), working with wheat traits, verified that especially the traits of grain yield, grain weight, number of ears per plant, number of grains per ear and plant height presented highly relevant genotypic and phenotypic correlations, which may be used indirectly to improve the other traits. Mohammadi et al. (2012) reported that, when analyzed a trait, such as grain weight that has a high magnitude genotypic correlation with grain yield, the use of this trait to assist in the plant genetic breeding is essential.

There was a positive effect of plant height and number of grains per ear on the genotypic correlations for all the analyzed traits, except for number of sterile spikelets per ear (Table 5), coinciding with the greatest direct and indirect effects on grain yield found in the path analysis (Figure 2). The number of grains per ear had the greatest direct effect on grain yield (Figure 2). According to Kavalco et al. (2014), the direct effect of a trait on grain yield, if positive, evidences the magnitude of the data and proves the veracity of these traits association; that is, there is efficiency in the use of the trait to increase the crop yield.
There was a significant environmental correlation for most the correlated traits, except for number of spikelets $\mathrm{m}^{-2}$ with grain yield, 1,000-grain weight and number of grains per ear, also verified in the correlation of 1,000-grain weight with the number of sterile spikelets (Table 5). The number of sterile spikelets directly affected the grain yield, with a high negative genotypic correlation observed between the two traits (Figure 2). There is also the effect of thermal stress, which may cause an increase in plant sterility. As reported by Demirevska-Kepova et al. (2005), the heat excess induces the occurrence of qualitative and quantitative losses for yield, such as reduced leaf area, plant height and percentage of flower fertilization, and also shortens the grain-filling period.

The path analysis provided a detailed notion of the trait influences directly and indirectly related to grain yield. There was no direct and indirect effect for number of ears $\mathrm{m}^{-2}$ on grain yield; however, there was a positive genotypic correlation between these traits. There was also a direct positive effect of plant height on grain yield and an indirect one on number of grains per ear, consistently with the high genotypic correlation between the two characters (Figure 2).

There was an indirect effect of the 1,000-grain weight on wheat grain yield via number of grains per ear and plant height (Figure 2). The genotypic correlation between the 1,000-grain weight and grain yield was positive and highly significant (Table 5). Traits that showed a high correlation with the dependent variable, but with a direct effect in an unfavorable sense, indicate the absence of cause and effect; that is, the trait is not the main determinant of changes in the basic variable and there are others traits that may have a greater impact on selection gain (Cruz et al. 2012). 


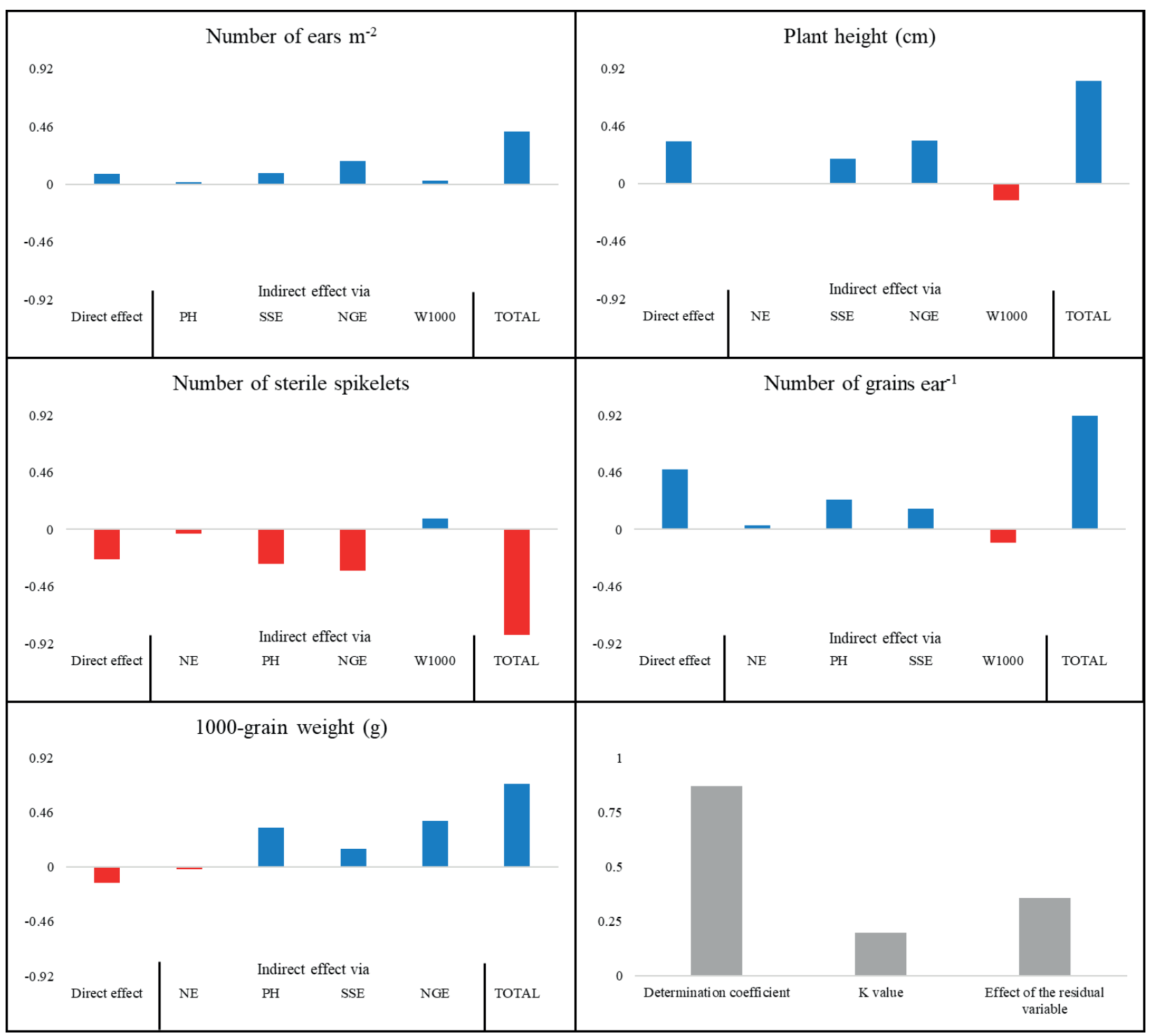

Figure 2. Estimates of the direct and indirect effects of yield components and plant traits on grain yield of wheat cultivars. The columns in blue explain the positive effects of the path analysis variables, the red ones the negative effects, and the gray ones represent the coefficients calculated and used in the path analysis. NE: number of ears $\mathrm{m}^{-2}, \mathrm{PH}$ : plant height (cm); SSE: number of sterile spikelets ear-1 ${ }^{-1}$ NGE: number of grains ear ${ }^{-1}$; W1000: 1,000-grain weight (g).

According to Cruz et al. (2012), for breeding purposes, it is important to identify, among the characteristics with high correlation with the dependent variable, those that have the greatest direct effect in favor of selection, in such a way that the correlated response through indirect selection is efficient. In the present study, it can be verified that the number of grains per ear and plant height showed a high genotypic correlation and a direct effect on grain yield.

A dissimilarity among the $\mathrm{A}, \mathrm{B}$ and $\mathrm{C}$ groups was found by the UPGMA clustering method calculated by genetic distances using the Tocher method. Group A was composed of the IPR 85 and CD 116 cultivars, group B of CD 108 and CD 150, and group C of IPR 136, IPR 144, BRS Pardela, IPR 130 and BRS 220. The greatest similarity between the cultivars was observed in the group C, with the highest number of cultivars with a shorter distance between them (Figure 3). The greatest distance occured between the groups $\mathrm{A}$ and $\mathrm{C}$, with the greatest genetic distance between the cultivars. The genotypes gathered in more distant groups are considered the most promising crosses; however, it 


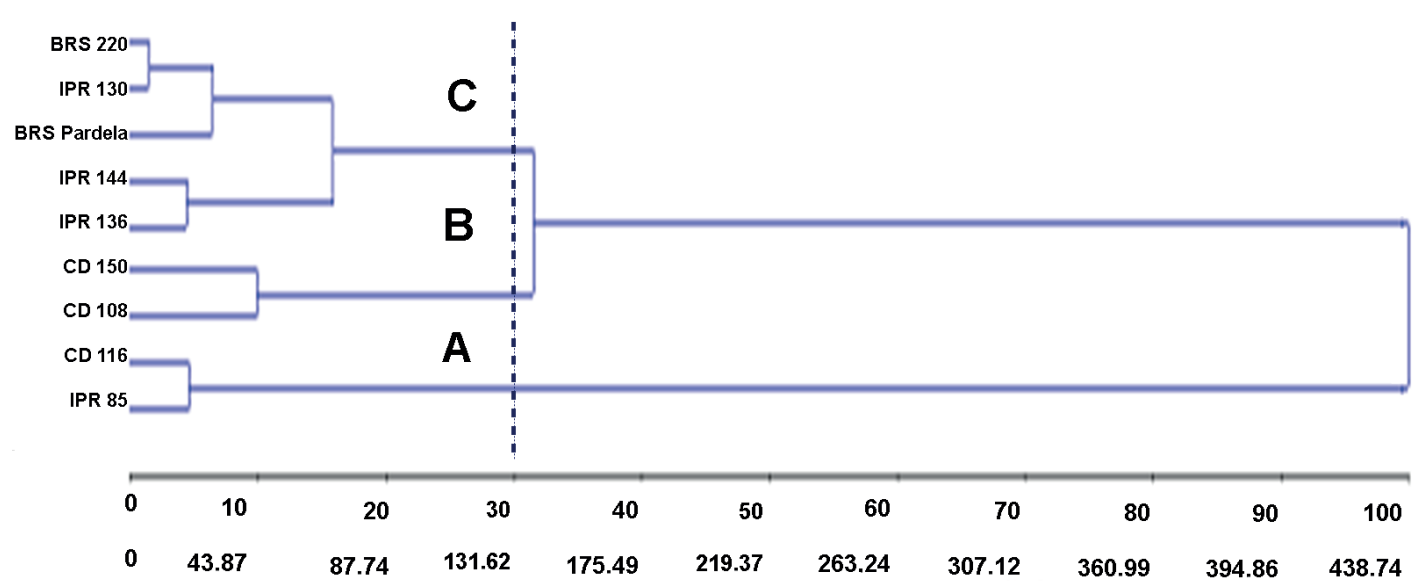

Figure 3. Dendrogram illustrating the dissimilarity pattern obtained by the unweighted pair group method with arithmetic mean (UPGMA), based on the Mahalanobis distance in wheat cultivars.

is necessary to consider the agronomic performance of the cultivars, so that they can increase desirable characteristics such as yield, to use them as a source of genetic variability to obtain high-yield potential cultivars (Almeida et al. 2011).

The UPGMA clustering method, based on the generalized Mahalanobis distance, is the most consistent and indicated to characterize the genetic divergence between cultivars, and provides a greater precision when selecting cultivars for future crosses (Araújo et al. 2014). The most productive genotypes in the summer period with high temperatures were CD 116 and CD 150, both present in different groups, suggesting that they have less similarity in response to cultivation in a stressful environment, being the most promising crossing with selection gain.

\section{CONCLUSIONS}

1. High temperatures affect the wheat spikelets fertility, grain weight and grain yield. The cultivars CD 116 and CD 150 were the most productive ones under heat-stress conditions, being considered as promising parents for plant breeding programs aiming to obtain heat-tolerant wheat cultivars;

2. The number of grains per ear is the most efficient trait for selecting high-yield wheat cultivars based on the path analysis under heat-stress conditions;

3. The greatest genetic divergence occurred between the groups A(IPR 85 and CD 116) and C (IPR 136, IPR 144, BRS Pardela, IPR 130 and BRS 220), while the cultivars from the groups A and B were the most tolerant to high temperatures.

\section{REFERENCES}

ALMEIDA, R. D.; PELUZIO, J. M.; AFFÉRRI, F. S. Divergência genética entre cultivares de soja, sob condições de várzea irrigada, no sul do estado do Tocantins. Revista Ciência Agronômica, v. 42, n. 1, p. 108-115, 2011.

ARAÚJO, L. F.; ALMEIDA, W. S.; BERTINI, C. H. C. M.; VIDAL NETO, F. C.; BLEICHER, E. The use of different clustering methods in the evaluation of genetic diversity in upland cotton. Revista Ciência Agronômica, v. 45, n. 2 , p. 312-318, 2014.

BIANCHI, F. G.; BALBI, R. V.; PIO, R.; BRUZI, A. T.; SILVA, D. F. Parents choice and genetic divergence between cambuci fruit tree accessions. Crop Breeding and Applied Biotechnology, v. 17, n. 3, p. 214-220, 2017.

CARGNIN, A.; SOUZA, M. A.; CARNEIRO, P. C. S.; SOFIATTI, V. Interação entre genótipos e ambientes e implicações em ganhos com seleção em trigo. Pesquisa Agropecuária Brasileira, v. 41, n. 6, p. 987-993, 2006.

CARVALHO, F. I. F.; LORENCETTI, C.; BENIN, G. Estimativas e implicações da correlação no melhoramento vegetal. Pelotas: UFPel, 2004.

CERQUEIRA-SILVA, C. B. M.; SANTOS, E. S.; JESUS, O. N.; VIEIRA, J. G.; MORI, G. M.; CORREAA, R. X.; SOUZA, A. P. Molecular genetic variability of commercial and wild accessions of passion fruit (Passiflora spp.) targeting ex situ conservation and breeding. International Journal of Molecular Sciences, v. 15, n. 12, p. 2293322959, 2014.

COAN, M.; MARCHIORO, V.; FRANCO, F.; EVANGELISTA, A.; GEREMIAS, K.; PATEL, V.; BALDISSERA, J. Genótipos de trigo e fontes de nitrogênio mineral e biológica no plantio direto. Revista de Ciências Agrárias, v. 56, n. 4, p. 292-298, 2013. 
COMPANHIA NACIONAL DE ABASTECIMENTO (Conab). Safra 2019/20: $8^{\circ}$ levantamento. 2020. Disponível em: https://www.conab.gov.br/info-agro/safras/graos/ boletim-da-safra-de-graos/levantamentosafra2018/2019. Acesso em: 30 out. 2020.

CRUZ, C. D. Genes: a software package for analysis in experimental statistics and quantitative genetics. Acta Scientiarum: Agronomy, v. 35, n. 3, p. 271-276, 2013.

CRUZ, C. D.; REGAZZI, A. J.; CARNEIRO, P. C. S. Modelos biométricos aplicados ao melhoramento genético. 4. ed. Viçosa: Ed. UFV, 2012.

DEMIREVSKA-KEPOVA, K.; HÖLZER, R.; SIMOVASTOILOVA, L. Heat stress effects on ribulose-1, 5-bisphosphate carboxylase/oxygenase, rubisco binding protein and rubisco activase in wheat leaves. Biologia Plantarium, v. 49, n. 4, p. 521-525, 2005.

DUTAMO, D.; ALAMEREW, S.; ETICHA, F.; ASSEFA, E. Path coefficient and correlation studies of yield and yield associated traits in bread wheat (Triticum aestivum L.) germplasm. World Applied Sciences Journal, v. 33, n. 11, p. 1732-1739, 2015.

HARSANT, J.; PAVLOVIC, L.; CHIU, G.; SULTMANIS, S.; SAGE, T. L. High temperature stress and its effect on pollen development and morphological components of harvest index in the $\mathrm{C} 3$ model grass Brachypodium distachyon. Journal of Experimental Botany, v. 64, n. 10, p. 2971-2983, 2013.

HUBNER, O. Trigo: safra 2009/10. 2010. Disponível em: http://www.agricultura.pr.gov.br/arquivos/File/deral/ trigo_relato_2009_10.pdf. Acesso em: 4 jun. 2018.

KAVALCO, S. A. F.; FIGUEIREDO, R.; GROLI, E. L.; ZIMMER, C. M.; BARRETA, D.; TESSMANN, E. W.; MAGALHÃES JÚNIOR, A. M.; OLIVEIRA, A. C. Pathway analyses in wheat genotypes under waterlogging stress. Semina: Ciencias Agrárias, v. 35, n. 4, p. 16831696, 2014.

KOUNDINYA, A. V. V.; DHANKHAR, S. K.; YADAV, A. C. Genetic variability and divergence in okra (Abelmoschus esculentus). Indian Journal of Agricultural Science, v. 83, n. 6, p. 685-688, 2013.

MOHAMMADI, M.; SHARIFF, P.; KARIMIZADEH, R.; SHEFAZADEH, M. K. Relationships between grain yield and yield components in bread wheat under different water availability (dryland and supplemental irrigation conditions). Notulae Botanicae Horti Agrobotanici ClujNapoca, v. 40, n. 1, p. 195-200, 2012.

MORAL, L. F. G. D.; RHARRABTI, Y.; VILLEGAS, D.; ROYO, C. Evaluation of grain yield and its components in durum wheat under Mediterranean conditions. Agronomy Journal, v. 95, n. 2, p. 266-274, 2003.
NARAYANAN, S. Effects of high temperature stress and traits associated with tolerance in wheat. Open Access Journal of Science, v. 2, n. 3, p. 177-186, 2018.

NAUDTS, K.; VAN DEN BERGE, J.; FARFAN, E.; ROSE, P.; ABDELGAWAD, H.; CEULEMANS, R.; JANSSENS, I. A.; ASARD, H.; NIJS, I. Future climate alleviates stress impact on grassland productivity through altered antioxidant capacity. Environmental and Experimental Botany, v. 99, n. 1, p. 150-158, 2014.

OLIVEIRA NETO, A. A.; SANTOS, C. M. R. A cultura do trigo. Brasília, DF: Conab, 2017.

OLIVEIRA, W. C.; FERREIRA, D. T. L.; LORENZETTI, E. R.; RUTZEN, E. R.; LIMA, P. H. P.; MALFATO, R. A. Influência de nitrogênio aplicado em cobertura na cultura do trigo. Cultivando o Saber, v. 4, n. 4, p. 113-128, 2011.

PAVAN, M. A.; BLOCH, M. F.; ZEMPULSKI, H. D.; MIYAZAWA, M.; ZOCOLER, D. C. Manual de análise química do solo e controle de qualidade. Londrina: Iapar, 1992. (Circular, 76).

RAO, C. R. Advanced statistical methods in biometric research. New York: John Wiley \& Sons, 1952.

SANTOS, H. G.; JACOMINE, P. K. T.; ANJOS, L. H. C.; OLIVEIRA, V. A.; OLIVEIRA, J. B.; COELHO, M. R.; LUMBRERAS, J. F.; CUNHA, T. J. F. Sistema brasileiro de classificação de solos. 3. ed. Rio de Janeiro: Embrapa, 2013.

SILVA, C. J.; SILVA, A. C.; ZOZ, T.; TOPPA, E. V. B.; SILVA, P. B.; ZANOTTO, M. D. Genetic divergence among accessions of Carthamus tinctorius L. by morphoagronomic traits. African Journal of Agricultural Research, v. 10, n. 52, p. 4825-4830, 2015.

SOUZA, M. A.; RAMALHO, M. A. P. Controle genético e tolerância ao estresse de calor em populações híbridas e em cultivares de trigo. Pesquisa Agropecuária Brasileira, v. 36, n. 10, p. 1245-1253, 2001.

VENCOVSKY, R.; BARRIGA, P. Genética biométrica no fitomelhoramento. Ribeirão Preto: SBG, 1992.

UNITED STATES DEPARTMENT OFAGRICULTURE (USDA). Soil Survey Staff. Keys to soil taxonomy. 12. ed. Washington, DC: USDA, 2014.

VIEIRA, E. A.; CARVALHO, F. I. F.; OLIVEIRA, A. C.; MARTINS, L. F.; BENIN, G.; SILVA, J. A. G.; COIMBRA, J.; CARVALHO, M. F.; RIBEIRO, G. Análise de trilha entre os componentes primários e secundários do rendimento de grãos em trigo. Revista Brasileira de Agrociência, v. 13, n. 4, p. 169-174, 2007.

WRIGHT, S. Correlation and causation. Journal of Agricultural Research, v. 20, n. 3, p. 557-585, 1921. 